Chapter in Nancy Lesko (ed), Masculinities at School, Sage, Thousand Oaks.

\title{
The 'facts of the case': gender equity for boys as a public policy issue
}

\section{Lyn Yates}

In many countries the final decades of the twentieth century have seen 'gender equity' enter the discussions of education policy, school systems, schools, education researchers. Today, a very widely held story about what has been happening would go something like this:

About twenty years ago, governments became aware that girls were being disadvantaged in schooling. They developed policies and funding to improve girls' career aspirations, to make curriculum and pedagogy more 'girl-friendly', and to ensure equal spending on girls and boys. At the same time a huge amount of research and writing was carried out on girls, their development and their needs. New textbook guidelines were introduced; ways of teaching were reassessed; forms of assessment were rethought; ideas about girls' psychology began to influence curriculum materials, classroom organization and teachers; concerns about the need in modern society for girls to be successful, to be mathematically literate and to take on a broader range of post-school careers were promoted with significant effect among teachers, parents and girls themselves.

The story goes on with the moral of the tale:

Over this period we have seen a large increase in the proportion of girls completing school as compared with boys, and their increasing success in 'non-traditional' subjects such as mathematics. Now it is time for more attention to the boys. Boys' 
retention rates, learning difficulties, delinquency, suicide rates and general selfesteem are all cause for concern. We don't want to take away from the girls' programs, and more needs to be done in relation to issues such as sexual harassment in schools, but there is a real dearth of good research and professional support for boys, and this is what should now occupy our urgent attention. ${ }^{i}$

This widely-repeated story gives rise to a number of interesting questions, both conceptual and 'factual'. What are the 'facts of the case' regarding sex-based inequalities and schooling and to what extent have these changed in the past two decades of reform activity? Just what sort of project is gender-focussed reform in schools? And, in policy contexts and in school reform agendas, what leads to certain claims (the needs of girls, say; or the needs of boys) being prominent or being no longer prominent?

In what follows, I want to look at some aspects of why as well as how boys and masculinity have become the interesting topic for policy-makers, media, and, indeed, for researchers such as myself. I will begin by revisiting the matter of inequalities, and will show that some elements of the story I have just outlined are quite misleading. However, I will argue, the particular form in which the concern about the boys is now being heard does point to some

\footnotetext{
${ }^{i}$ Earlier versions of the present chapter were given as a paper presented at the 1996 AERA Conference in New York, and in the form of an article, 'Gender Equity and the Boys Debate what sort of challenge is it?', published in the British Journal of Sociology of Education, 18 (3), 1977, 337-347. This 'story' that I have paraphrased in the opening is one I have seen represented in magazines, newspapers, television programs, government-commissioned reports and has been the theme of a number of academic conferences and writings. Three useful books which take up this story and provide interesting discussions of it in ways that are complementary to the present chapter are: MacKinnon, Elgqvist-Saltzman and Prentice (1998), a collection of papers arising from an international feminist conference held in Umea, Sweden in 1995, at which reflection on past gender equity initiatives, and a concern about the ubiquity of the 'what about the boys?' question was a central focus of the discussions; Arnot, David and Weiner (1999), a UK book arising from a government-initiated consultancy project to assess how the relative equity issues of females and males had been affected by various reform initiatives of past decades; and Lingard and Douglas (1999), a book about the current varied forms of men's relation to feminism and to gender equity issues in education, which includes a good discussion of some major popular publications and debates on these issues around the world.
} 
interesting issues about school reform and gender issues. These relate to the treatment of inequalities within the shaping of public policy; to curriculum and pedagogy matters of just how 'gender' is to be 'reconstructed'; and to research methodologies, and what frames our interests and interpretations as researchers.

What follows, then, is not an attempt to give a comprehensive overview of the developments in relation to boys. It is an attempt to illuminate some aspects of these developments. And it is specifically grounded in an Australian context, where gender equity has been a very prominent reform program and where current discussions about boys are more strongly concerned with 'equal opportunity' and men's movement concerns than with fears about gendered and racial patterns of poverty and violence in society, which seem to have been more prominent in public discussions about boys in the USA and in the UK. The present discussion is not intended to suggest that the issues I raise are the only matters of relevance in current debates and in the changing agendas (some good discussions of other aspects of the issue can be found in MacKinnon et.al., 1998; Arnot et.al., 1999 and Lingard and Douglas, 1999), but to discuss one specific set of developments and to add some areas of discussion to the interpretation of the new developments.

\section{Policy and politics: debates about inequality and equal opportunity}

Just how much was the policy attention to girls a response to facts about inequality and disadvantage, facts that have now changed and justify a new attention to boys on the same grounds? The answer is complex.

In the mid-1970s, in one of the government inquiries in Australia which investigated and justified the need to give more attention and support to girls in school, one member insisted on producing a Minority Report in which she argued that to see girls rather than boys as the disadvantaged group was a distortion of reality: 
Those who have experienced racism know how false are the analogies drawn between sexism and racism, and the equation of female 'liberation' with models of liberation from colonial rule. When assessing the status of any disadvantaged or under privileged group, e.g. the blacks in the U.S. or Aboriginals in Australia, a number of criteria are used: infant mortality, life expectancy, incidence of disease, alcoholism, violence, involvement with drugs, crime, imprisonment, level of literacy, retentionrates at school, success rates in examinations, employment and income levels. Applying these criteria to males and females in Victoria, on every count except the last, it is males who emerge as the disadvantaged group.

(Victorian Committee on Equal Opporunity in Schools, 1977b, piii)

Now we might complain about the way the list of 'indicators' here is loaded (literacy but not mathematics; alcoholism but not those on welfare payments; imprisonment rates, but not rates of those in political office, etc.), but I want to draw attention to something else. In the 1970s, the statement just quoted was very much a minority voice. It was circulated, but otherwise, for school reform purposes, effectively ignored.ii Yet, in terms of its 'factual' underpinnings, and for the categories that are included, the case made in this statement is, broadly, correct - both two decades ago, and also today.

Then, as now, males rather than females predominated among those falling behind in school and being sent to 'special education' classes. Then as now, teenage boys were much more

ii I need to make a qualification here. Funding was being spent on areas such as remedial education, delinquency, etc which gave heavy attention to boys. But, in contrast to the present-day debate, such funding was not seen as connected with concerns about gender, masculinity, or sex-based equal opportunity in schools. Indeed one of the problems spawning backlash responses to funding of girls' and women's programs over the last two decades is that these have always been very explicitly tagged as 'girls' or 'gender equity' spending, whereas the funding which in fact goes to boys and men often has more innocuous labels, such as 'sports funding', ' remedial programs', 'special reading programs' etc. A recent study in the UK has found this pattern in the allocation of special needs provision and makes some interesting points both about how such provision is unequally distributed along gender and race lines. (Daniels, Hey, Leonard \& Smith, 1996) 
likely to commit suicide than teenage girls. Then, as now, girls' overall broad retention and success rates in school were not of the pattern that was previously associated with 'disadvantaged' groups. But then, as now, women went on in later life to have much poorer incomes and employment achievements than do men. (Australian Bureau of Statistics, 1993; Yates, 1986, 1993a; Kenway, Willis and Junor, 1995; Yates and Leder, 1996) Equally, none of these 'indicators' have an unproblematic meaning, but that is an issue for other discussions. ${ }^{\text {iii }}$

To take one example: school retention rates were, and are, a traditional indicator of (classbased and race-based) inequality, but, in the statistics quoted in the 1975 Australian report which represented the initiating case launching a reform policy agenda for girls, the gap between the overall retention rates of girls and those of boys was extremely small (boys: 34.1\%; girls 31.7\% - and girls' retention rates passed those of boys in 1976), whereas class differences at the same period were extremely large (as one crude indicator, the retention rates of private schools were $90.3 \%$ and those of government schools, $27.3 \%$ ). There were significant differences in patterns of subject-choice and success in mathematics and science, but to some extent the dramatising of these rather than overall retention as indicators was a consequence rather than source of the concerns about what happened to girls. And there were very significant sex-based differences in entry to higher and further education. There were certainly grounds for being concerned about what happened to girls through schooling, but what I am trying to show is that the pattern of what is picked up as a significant feature of schooling shifts. Some broadly similar interpretations can be made using data in the US report, How Schools Short-change Girls (AAUW, 1992), which is not simply a story that girls do badly at school.

iii In another project (Yates and Leder, 1996) we investigated the meaning and problems of 'indicators' used in various government data-bases in Australia: how they were defined, how the data was collected, what was left out, what perspectives and biases the measure produces about factors such as gender, ethnicity, disability, etc. The report from this study (available from the author) provides a major index, review and critical discussion of the categories and indicators used in national data-bases in Australia. 
So the present debates somewhat misrepresent the nature of the inequalities from which the gender reforms began. Women and girls did experience social inequalities and this fed a new attention to which aspects of educational processes were contributing to this (particularly subject-choice, careers advice, share of teachers' attention). But on many other measures, in relative terms, even in the 1970s, girls were doing well at school. Similarly, boys' problems at school had already long been a subject of fascination for sociologists (dropping out, school resistance, delinquency), educational psychologists (remedial teaching) and policy-makers. It was not the discovery that girls and not boys had problems that prompted the new reform, but a social movement, the Women's Movement, and the broader work, social and cultural changes of the late twentieth century. These spawned a new concern about girls' outcomes from their education and a new commitment to investigate how girls' problems had been made invisible in the previous research and policy agendas, and to attempt to redress this. (Yates, 1993a, 1998b)

In emphasizing some ways in which the 'facts' about education patterns such as retention were not markedly different from those now being 'discovered' and used as justification in the call for new attention to boys, I am not suggesting that no specific problems regarding girls were identified, nor that the education pathways and outcomes for girls and boys have remained unchanged. In Australia as well as in the UK and Scotland (Arnot, David and Weiner, 1996; 1999; Powney, 1996) there has been both absolute and relative improvement in the educational achievements of girls. In the world economy too, there has been a significant re-shaping and re-locating of work, involving the loss of many areas of traditional male employment. But a number of the grounds on which the case for attention to the boys is now being justified existed and were known at the beginning of the wave of reforming policy directed to girls. Yet at that time it was widely accepted that, in so far as policy reforms needed to deal with 'gender' and 'sex equity', then they were an issue about girls and women, not boys and men, whereas today they are taken as a legitimate, indeed compulsory, concern 
for gender equity programs (O'Doherty, 1994; Browne and Fletcher, 1995; West, 1996; MCEETYA, 1995; Gilbert and Gilbert, 1998; Lingard and Douglas, 1999).

So it is not, after all, a simple story where the 'disadvantage' of girls was discovered, attended to, at least partially fixed up and then replaced by some of the same processes in relation to boys. The 'facts of the case' are a useful reminder that the discourse, the broad context of action and research ('sex equity', 'gender-based reform') assumes a taken-for-grantedness that hides the politics of what is being taken up, and whose definitions are being taken up.

\section{Who is disadvantaged and what does inequality look like? What is 'sex equity' and 'gender-based reform' about?}

Projects of gender equity in schooling, though by no means uniform in their politics or their framing assumptions, have been broadly concerned with inequalities and also with reassessing and changing school's part in the formation of gendered identity (student selfperceptions, values, ambitions, skills, social relationships) ${ }^{\text {iv }}$. The current concerns about boys pose a challenge to elaborate at a public level the broad agendas framing both enterprises.

The projects and discussions concerned with boys are not unitary (for good overviews see Connell, 1995; Gilbert \& Gilbert, 1998; Lingard \& Douglas,1999). Some writers such as Connell (1989, 1994, 1995), Maclean (1995), Gilbert and Gilbert (1998), Lingard \& Douglas (1999) have contributed complex analyses and research on the subject. But public and popular accounts of the need to reform schooling for boys most commonly draw on two simple themes: that it is boys who are now 'losing out' at school, as evidenced by changing

iv In other writings (especially Yates, 1993b and Yates, 1998a) I have discussed differences and changes in the ways girls have been conceptualized as an object of educational research and reform and, implicitly, the fallacy of accounts (such as Moore, 1996) which reductively portray this as a simple and self-contradictory project concerned with 'disadvantage'. 
patterns of results in the final examinations; and that what is needed is to take over strategies that have been successful for girls, and apply these to boys.

In the next sections of this chapter I want to look at some assumptions and implications of those commonly heard themes. This popular form of the challenge to focus on boys, I will argue, sets aside the actual social/economic significance of the examination results which are the focus of so much attention; sets aside the historical construction of schooling as the site of gender reform; and, above all, fails to deal adequately with power and with masculinity and femininity as relational phenomena.

\section{Inequalities and Examination Results as a Benchmark}

Recent discussions about changes in the patterns of final examination results of girls as compared with boys, have led to some detailed debate about which groups are and are not successful here, and which groups are and are not advantaged by current assessment and ranking procedures (see Foster, 1994; Teese et.al., 1995; Davy, 1995; Arnot et.al., 1996; Powney, 1996). What is less remarked on is the assumption being made about the significance of school final year results as the benchmark for assessing inequalities.(Yates and Leder, 1996)

The specific event that sparked a major Australian inquiry into boys and education (O'Doherty, 1994) was the publication of some final year school statistics in which girls, for the first time, gained some of the highest mathematics results. The results that drew the debate concerned a minority of students, those students doing the very 'hardest' subjects, and getting the very highest results. The newspapers, which have a long-standing pre-occupation with the top results in the annual examinations, seized on some results where girls, for the first time, were top students in the highest level mathematics subjects, as evidence both of an enormous turnaround in gender patterns in school, and as a signal that something now had to 
be done about the 'underachievement' of boys. (This debate is discussed more fully by Foster, 1994.)

The results under discussion were a change in the patterns of school success, in that, for a long time, although girls had been successful in many areas, success in the 'highest' levels of the very 'hardest' subjects had eluded them. But the emphasis given to this particular change very much narrowed and abstracted the focus on gender and inequality.

For almost twenty years, girls' overall retention and success rates in Australian schools had been higher than those of boys - but, in relation to girls, those examination statistics had never sufficiently described or accounted for the patterns of sex related inequality in schools. Although girls' lesser participation and success in mathematics contributed to their more restricted educational and employment paths beyond school, the latter went far beyond what could be accounted for by the former (see Yates, 1993a). And the projects of gender reform for girls in schools had been concerned about inequalities in the curriculum and processes of schooling, about how schooling was contributing to different futures for girls and boys by what they learnt there, how they developed there - and not just by what examination score they obtained. (That is, relative to a particular level of actual school success in mathematics, girls, on average, would make less of it in terms of future educational career and in terms of eventual career pay-off.)

Reports on girls and inequality did look at patterns of school success, but they also drew attention to the different outcomes of schooling for girls, to the ways school directed and limited the paths taken by girls (stereotyping women; directing girls to a narrow range of post-school courses and jobs); and to ways curriculum and pedagogy was biased in taking men and not women as actors in the world, and in treating women and girls as 'other'.

Given this background, to argue that it is boys rather than girls who now need to be seen as the focus for sex equity work should require some attention to (a) whether the 'pay-off' of 
schooling for girls has now been turned around, and (b) whether school curriculum and pedagogy is now focussed on women and girl's ways of knowing and their interests. Simply showing that girls' retention rates have continued to grow, or that some girls have increased their participation in mathematics and their success in this, is not enough.

Weiner, Arnot and David (1997), make a similar point about the debate as it has been shaped in the UK: 'Significantly, this pattern of male advantage in employment which is common in both the public and private sectors, is not alluded to within the current educational discourse of male disadvantage.' David also makes the point that

It is a comparative statement that boys are doing less well than girls. However, all boys and all girls are doing better than they did five years ago.

(in Kemal et.al, 1996, p.69)

In fact, in Australia, the picture regarding what has happened to males and females as a result of school reforms and labour market changes is mixed. While there has been change in some 'outcomes' areas (more women now undertake degrees, and more enter medicine and law; and there has been some decline in women's unemployment rates), there is also evidence of lack of change in others: overall, women in Australia still enter a relatively narrow range of jobs, are a minority in the senior ranks of most areas of employment and particularly in business, and their average weekly incomes relative to men improved steadily from the early 1970s until the mid-1980s, but have remained static since the late 1980s at around 83\% (Australian Bureau of Statistics,1993; Kenway, Willis and Junor, 1995; Walpole,1995).

So the continued focus on a small section of the year 12 results as if they are a straightforward indicator of what schooling does for girls and boys is misplacedv. This

\footnotetext{
v On this issue there is a significant difference between Australia and England. In England (but not Scotland, cf Powney, 1996), there has not been the same extent of achievement in relative success by girls at A-level; and the 'turn-around' in achievement patterns that underlies much discussion is more strikingly seen at GCE (Arnot, David \& Weiner, 1996), and is more commonly discussed in relation to working-class boys (David, Arnot \& Weiner,
} 
popular way of taking up examination results gives undue emphasis to what is happening to a small group at the top, in the process drawing attention away from how class differences operate within the groups of girls and boys. This approach not only constructs 'girls' and 'boys' as unitary categories rather than categories permeated by educationally important differences, it also deals inadequately with how gender is part of the process. By abstracting out the single indicator of year 12 results, the discussion fails to consider the specificity of the form of girls' inequality (as discussed above), and it also deals poorly with masculinity and with how gender can contribute to some patterns of failure for boys and to restriction in 'pay-off' for high-ability girls. The suggestion is that if there are some lesser results of boys, then it must be due to girls having been given special assistance in recent years, or to school and assessment authorities now having adopted 'girl-friendly' strategies and failing to institute 'boy-friendly' equivalents. Conceptually, the issue of girls and boys, pedagogy and outcomes is treated as a rather mechanical process, in which discrete advantages are bestowed on groups through techniques of particular kinds.

Richard Teese's work however suggests that it is possible to look at the broader patterns of subject-choice, success and failure with more subtle assumptions about gender as a phenomenon - assumptions that see gender as relational, and subject choice and success as being embedded in broader discursive constructions of masculinity and femininity (and class and ethnicity).(Teese et.al., 1995) From a major survey of Australian year 12 subject-choice and assessment results, Teese argues that gender contributes to a much broader failure of boys than that picked out by the focus on a few top students - in that it persuades boys to 'over-enrol' in mathematics, and thus to produce a greater overall proportional failure for boys in this area - a pattern which has been evident for some time. Similarly, Teese argues, gender (in conjunction with the structure of the assessment system) contributes to a phenomenon of high ability girls not getting the rewards and outcomes which accrue to high

1996) But in each case, my point remains: that patterns of school achievement need to be read in the context of other social indicators. 
ability boys (in that humanities choices bring penalties in relation to maximizing one's score and one's post-school career rewards).

\section{Gender Reform Strategies}

Just as the public discussion of year 12 results in Australia has tended to detach 'sex equity' comparisons from the broader social location and effects of schooling, some of the reform strategies now being suggested for boys also take up the issue as if it were about abstracted technologies for success, rather than related to historical and social constructions. ('Sex equity' is also itself a problematic term, which encourages detached mathematical comparisons, rather than attention to social meanings of equality and inequality.) The quote which follows, taken from the foreword to a recent book on Boys in Schools intended for teachers, takes up the rhetoric earlier applied to reforms for girls:

Boys will change when they are helped to understand themselves better, are affirmed and valued 'as they are' and are given the tools to feel safe and equal around girls. [...] It's time we honoured and put a positive value on the unique qualities of boys.

(Biddulph, in Browne and Fletcher, 1995, pp.ix, x)

This quote takes up the rhetoric of the earlier reforms directed to girls, but ignores both the institutional history of schooling and the concern about gendered power relations that formed their social foundations. For the past decade or two there has been, in Australia, some funding, research and professional development specifically focussed on girls, but this does not reproduce for boys a mirror image of the situation in which girls were earlier seen to be disadvantaged. Textbooks today are not full of women and silent about men; the 'reproductive' aspects of society (cf Martin, 1982; Foster, 1995) are still a minor and lowstatus element of the curriculum; and pedagogies which benefit girls have not made boys invisible to the teachers. 
Even the concern about school practices limiting students by the ways they construct femininity and masculinity is not a mirror image argument for boys and girls (as Connell,1989, 1994 and Maclean, undated; Maclean,1995 have well argued). Individual boys (or categories of boys) may be distressed by their failure to measure up to desired masculine attributes such as sporting prowess, size, technical and scientific achievement; but those characteristics of 'hegemonic masculinity' (to quote Connell) were ones that bring social power, status, financial reward. In the case of girls, however, a starting point agenda was that even what schools promoted for girls was socially disabling:

An observer not raised with our cultural assumptions would be struck by the fact that one half of the population was assigned by birth to activities which, whatever their private gratifications and social importance, carried no economic reward, little public status, and very limited access to public power.

(Schools Commission, 1975, p.8)

The distinctions here are of considerable significance in terms of reform strategy and of policy in relation to public schooling. Both girls and boys may be made unhappy by their failure to measure up to what is ostensibly promoted and valued by schooling, or their peers, or the media. But a strategy whose aim is simply to extend the public power and status outcomes of the group in question is very differently located than one whose aim is to reduce or redirect that group's share of public power or is to challenge more broadly what is currently valued and rewarded in the broader society. The problem here is one which affects both the public policy formulation level of gender reform, and also micro level strategies of gender projects.

\section{Reform agendas and their limits within public policy}


Earlier I suggested that the recent taking up of boys' issues as a key concern in gender equity work was not simply a response to changes in patterns of school success or of social inequality. I now want to consider further why the boys' agenda may have arisen at this point, and the issues that this raises in relation to gender matters and school reform.

In Australia, the debate about boys' results took off not when it was discovered that boys, proportionally to those doing it, failed mathematics in higher numbers than did girls - that had been the case for some time. ${ }^{\text {vi }}$ It was a response to boys beginning to lose out to girls in the very top categories. vii I would argue that the way in which this debate broke out, and the way it has been handled, point to some features of the sources and the discursive form of public policy. The case-study of Australia which I will discuss I would suggest points to processes that can be seen in other countries, but with some contextual specificity. I am aware that the specific form of final school assessment and tertiary entrance, and the public discussions in Australia more clearly take mathematics as the singular privileged indicator of prestigious intellectual achievement than do some other countries (consider the UK A-levels, for example; or even more strikingly, Bourdieu's discussions of France).

In Australia, one notable feature of reforms concerned with girls has been that many of the beneficiaries have been middle-class girls. Private girls' schools have taken up feminist agendas even more strongly than public schools (Connell et.al., 1982; Abbott-Chapman et.al., 1991, and annual reports on Girls in School produced by the national Department of Employment, Education and Training since 1988). There has been an articulate and strong middle-class lobbying for women's interests in education. So, one might argue, for some

vi Though boys had proportionally higher failure rates, many more boys were taking higher level mathematics, so despite the higher proportion failing, the actual numbers of those passing it were still considerably greater than the number of girls.

vii It was also influenced no doubt by the steady growth in the numbers of girls taking these subjects, though they are still distinctly outnumbered by boys. (see Teese et.al., 1995; Foster, 1994) 
time, the gender agenda has represented an extension of middle-class interests without threatening middle-class interests.

The examination results which sparked the debate and inquiry however introduced something new onto the scene: the issue that there is some zero-sum aspect to schooling achievement patterns. Now it is becoming apparent that it is not only working class boys and men who are being affected by the changes of recent years (many manual jobs were the first to disappear) it is middle class boys who may be being 'deprived' of a place in medicine because a girl has done better; or who may be being 'deprived' of optimum learning conditions because girls are going off to single-sex classes rather than being a supporting influence on their own learning environment (Foster, 1995). So two things are happening here: a threat to the group whose power has been greatest, and also the beginnings of an inkling that gender reform programs cannot just go on improving the competitive outcomes of schooling for some students without, in relative terms, affecting the outcomes of others.

What I have been suggesting in these sections is that the coming into force of the challenge to look at boys in gender work in schools raises more far reaching problems than the problem of 'what to do about the boys'. It raises the problem of how gender equity in general can be maintained as a public policy issue. Schooling is a selecting mechanism in relation to postschool power, income, privilege, but the policy discourse is one in which it is only possible to talk about improving outcomes for groups without acknowledging that it is not possible for all students to get the good jobs, and that it will not be politically acceptable to pursue a policy where those who already have power see the chances of their own children being overtly undermined. Debates of this kind have been seen already in relation to 'Affirmative Action' programs in employment, but, until recently, in Australia, the idea that the increasing success of girls might have implications for boys, and for particular groups of boys, was not explicitly discussed or obvious. 


\section{The complicity of academic researchers in changing policy agendas}

One of the aspects of the present debate that is most irritating to those who have been working in the gender area for the past two decades is the charge that there is a desperate need for research about boys because research to date in the gender area has been feminist research which is only concerned with girls.

A consideration of gender, by its nature, has involved the development of theories and frameworks for investigating how women and men and how femininity and masculinity work: their discursive construction, their patterns of achievement and life patterns, the meanings and implications of 'gendered subjectivity' and so on viii. The lines of research and strategy being discovered and 'created' by those working on boys (West, 1996; Browne \& Fletcher, 1995) often directly borrow earlier frameworks and findings of feminist gender research: concerns about role models, consciousness-raising, concern for boys who are teased because they are not sufficiently masculine, and so on.

And yet it is also true that the great bulk of empirical qualitative work on gender, pedagogy, subjectivity and schooling in the past two decades has studied girls rather than boys. Frameworks and theories might have been concerned with both, but the substantive 'findings' and insights were not equally spread.

This issue and its implications have been brought to my own attention by the experience of embarking on a new empirical study after some years of focussing mainly on theory and documents. The study (Yates \& McLeod, 1996; McLeod \& Yates, 1997) is a qualitative, interview-based, longitudinal study of girls and boys at four different schools from the

viii Feminist research has not been the only way into these issues. Paul Willis's important 1970s study of working class masculinity developed from an interest in class-focussed ethnography; and many studies (more commonly in the USA and the UK than in Australia) have developed research on gender as an outcome of a focus on race. 
beginning to the end of high school.

In the project we are interested in some things that have been the focus of a great deal of research in the gender area - including the development of gendered subjectivity over the secondary schooling years, and the workings of gender in relation to schooling and out of school life over that time. What we found when we were looking at and attempting to interpret the tapes from our first round of interviews was that the boys in our study seemed interesting and our findings there 'unexpected', whereas (for the purposes of research publication) we could find little to say about the girls. But, being good postmodern reflexive researchers, we were equally aware that this reaction was as much a comment on us and what we were bringing to the research as it was on what we were 'finding'.

To take one example, the boys' responses (at the end of primary school) to how they would describe their friends (being interviewed with them) spoke much more about caring and supportive relationships than we had expected.(Yates and McLeod, 1996) The boys fantasized about sport, but also (in a number of cases) about their future married life. As well, we noticed considerable differences between the boys in our study. Now we could describe findings about the girls which parallel the points crudely summarized here: many girls in the study were widely and intensely interested in sport and fantasized about future stardom in that arena; they too differed markedly in their values and hopes. As feminist researchers however, we expected all this - a legion of books had now told us not to see girls in an essentialist way. We also expected boys not to be a uniform group - in principle. But in practice, we became aware that much of the feminist literature on schools with which we were familiar (particularly the literature directed to school-based action) did treat girls in sensitive detail, while leaving boys as a more shadowy 'other'; and treated masculinity as a 
more crudely sketched out discourse against which femininities were examined.

My experiences in this project also touch on ways in which as researchers we find ourselves driven by some of the same forces (such as the search for a new issue) that can be seen in the press debate. An area of research and action (girls and gender) can begin to seem like 'old news', in Thomas Kuhn's terms to be a paradigm that is providing fewer rewards, or in the harsh context of funding decisions, to be less attractive to funding bodies than the new public concerns about boys. Here I think there is some parallel with the way class issues have become a less prominent area of sociological research on education since the 1970s. Whatever the reason, it is clear from publishers' lists that at this time, very large numbers of researchers have begun to develop an interest in boys as an important issue and thereby to feed as well as benefit from the dominance of this issue within public policy 'gender equity' debates - a trend in which I am clearly myself a non-innocent participant.

'Facts', truths, public stories, inequalities, feminism...

This has been a discussion intended to disrupt some taken-for-granteds of the public form of the emerging boys' gender equity agenda, and to reflect on some different practices and the ways they convergence - of class and gender interests; of researchers and the fields they ostensibly address. To go back to my starting story and my questions about this, what are the implications of what I have said?

First, on inequalities, there is more than one set of 'facts' and more than one story to tell, even about the same set of figures. The issue of schooling and 'gender equity' can look different if you abstract and focus on comparisons at one point (drop-out rate, or final achievement 
patterns, for example), than if you start with broad social patterns of gendered inequality and relate these to the education processes that produce them (which are not simply relative achievement); and of course all of these look different again if you work with class- and racedifferentiated analyses rather than unitary ones.

Second, on policy agendas, we see through the changes of the last few decades the way in which social changes and movements can bring new issues onto the policy agenda (gender equity), but in which there is an ongoing 'taming' and reclaiming of these in terms of dominant interests and in terms of how questions may be addressed. Mathematical, categorical comparisons are a common and acceptable tool; claims related to past injustices, or to adjusting the type of social 'goods' that are being promoted are making much less progress.

The 'what about the boys?' debate has marked an interesting shift in the discursive field of gender and schooling. Why it has arisen, which boys are getting attention, what is now being defined as the evidence of 'inequity' and the agendas for further action are the questions which have been the subject of this chapter. These are all issues which warrant attention alongside the empirical investigations and the claims that are too easily taken for granted as 'the facts' of the case. 


\section{Acknowledgement:}

I would like to thank Jane Gaskell and Julie McLeod for comments on an earlier draft of this paper, and for more general discussions about some of these issues 
References:

ABBOTT-CHAPMAN, J., HUGHES,P. \& WYLD,C. (1991)

Participation and Retention Rates and Social and Educational Factors which are related to them in Tasmania (2 vols) (Hobart, Centre for Education, University of Tasmania).

ARNOT,M., DAVID,M. \& WEINER,G. (1996)

Educational Reforms and Gender Equity in Schools (Manchester, Equal Opportunities Commission).

ARNOT,M., DAVID,M. \& WEINER,G. (1999)

Closing the Gender Gap: Postwar Education and Socical Change (Cambridge, Polity)

AMERICAN ASSOCIATION OF UNIVERSITY WOMEN (1992)

How Schools Short-change Girls (Washington, AAUW).

AUSTRALIAN BUREAU OF STATISTICS (1993)

Women in Australia (Canberra, Australian Bureau of Statistics).

BROWNE,R. \& FLETCHER,R. (1995)

Boys in Schools (Lane Cover, Finch Publishing).

CONNELL, R.W., ASHENDEN,D., KESSLER,S. \& DOWSETT,G.W. (1982)

Making the Difference (Sydney, Allen \& Unwin).

CONNELL, R.W. (1989)

Cool guys, swots and wimps: the interplay of masculinity and education, Oxford Review of Education 15 (3), pp. 291-303.

CONNELL, R.W. (1994)

Knowing about masculinity, teaching boys and men, in J.LEMAIRE (Ed), Girls, Boys and Equity: a practical resource for use in schools (Sydney, NSW Teachers Federation).

CONNELL, R.W. (1995)

Masculinities (Sydney, Allen \& Unwin).

DANIELS,H., HEY,V., LEONARD,D. \& SMITH,M. (1996)

Gender and Special Needs Provision in Mainstream Schooling, ESRC End of Award Report, July 1996.

DAVID,M., WEINER,G. \& ARNOT,M. (1996)

Feminist approaches to gender equality and schooling in the 1990s. Paper presented to the AERA Conference, New York. 
DAVY,V. (1995)

Reaching for consensus on gender equity: the NSW experience, Proceedings of the Promoting Gender Equity Conference (Canberra, ACT Department of Education).

FOSTER,V. (1994)

"What about the boys!" Presumptive equality, and the obfuscation of concerns about theory, research, policy, resources and curriculum in the education of girls and boys, Paper presented to the Australian Association for Research in Education Annual Conference, Newcastle.

FOSTER,V. (1995)

Citizenship education and Whereas the People... Another case of "add women and stir?" in: L.YATES (Ed), Citizenship and Education (Melbourne Studies in Education 1995, La Trobe University Press).

GILBERT,R. \& GILBERT,P. (1988)

Masculinity Goes to School (Sydney, Allen \& Unwin).

KEMAL,S., LEONARD,D., PRINGLE,M. \& SADEQUE,S. (Eds) (1996)

Targeting Underachievement: Boys or Girls? (London, Centre for Research and Education on Gender).

KENWAY,J, (with WILLIS,S., BLACKMORE,J. \& RENNIE,L.) (1993)

Learning from girls: what can girls teach feminist teachers?, in: L.YATES (Ed) Feminism and Education (Melbourne Studies in Education 1993, Trobe University Press).

KENWAY,J. \& WILLIS,S. with JUNOR,A. (1995)

Dangerous Opportunities: gender and the restructuring of work and vocational education (Melbourne, Victorian Education Industry Partnerships Forum Series).

LINGARD,R. \& DOUGLAS,P. (1999)

Men Engaging Feminisms: pro-feminisms, backlashes and schooling (Buckingham, Open University Press).

MACLEAN,C. (undated)

Boys and education, in: DULWICH CENTRE, Men's Ways of Being (Adelaide, Dulwich Centre Publications)..

MACLEAN,C. (1995)

The costs of masculinity: placing men's pain in the context of male power, Proceedings of the Promoting Gender Equity Conference (Canberra, ACT Department of Education).

MARTIN,J.R. (1982)

Excluding women from the educational realm, Harvard Education Review, 34 (4), pp.341-353. 
MACKINNON, A., ELGVIST-SALZMAN,I. \& PRENTICE,A. (ed.) (1998)

Education into the $21^{\text {st }}$ Century: dangerous terrain for women? (London, Falmer Press)

MARTIN,J.R. (1994)

Methodological essentialism, false difference, and other dangerous traps, Signs 19 (3), pp. 630-657.

MCLEOD,J. \& YATES,L. (1997)

Can we talk about girls and boys today, or must we settle for just talking about ourselves. Dilemmas of a feminist, qualitative, longitudinal research project, Australian Education Researcher, 24 (3), 23-42.

MINISTERIAL COMMITTEE ON EMPLOYMENT, EDUCATION, TRAINING AND YOUTH AFFAIRS (AUSTRALIA) (1995)

Proceedings of the Promoting Gender Equity Conference (Canberra, ACT Department of Education).

MODLESKI,T. (1991)

Feminism Without Women: Culture and Criticism in a "Post-feminist" Age (New York, Routledge).

MOORE,R. (1996)

Back to the future: the problem of change and the possibilities of advance in the sociology of education, British Journal of Sociology of Education, pp. 145-161.

O'DOHERTY,S. (Chair) (1994)

Challenges and Opportunities: a discussion paper, Report to the Minister for Education, Training and Youth Affairs on the Inquiry into Boys' Education 1994 by the NSW Government Advisory Committee on Education, Training and Tourism (Sydney, NSW Government).

POWNEY,J. (1996)

Gender and Attainment: a review (Edinburgh, Scottish Council for Educational Research).

RILEY,D. (1988)

"Am I That Name?" Feminism and the Category of "Women" (London, Macmillan).

SCHOOLS COMMISSION (AUSTRALIA) (1975)

Girls, School and Society (Canberra, Australian Government Printing Service).

TEESE,R., DAVIES,M., CHARLTON,M. \& POLESEL,J. (1995)

Who wins at school? Girls and boys in Australian secondary education (Melbourne, Melbourne University Department of Education Policy and Management).

VICTORIAN COMMITTEE ON EQUAL OPPORTUNITY IN SCHOOLS (1977a)

Report to the Premier of Victoria (Melbourne, Government Printer). 


\section{VICTORIAN COMMITTEE ON EQUAL OPPORTUNITY IN SCHOOLS (1977b)}

Minority Report (by Babette Francis) (Melbourne, Government Printer).

WALPOLE,S. (1995)

Gender equity in education: a view from outside the classroom, Proceedings of the Promoting Gender Equity Conference, (Canberra, ACT Department of Education).

WEINER,G., ARNOT,M. \& DAVID,M. (1997)

Is the future female? Female success, male disadvantage and changing gender patterns in education, in: A.H.HALSEY, P.BROWN \& H.LAUDER (Eds) Education, Economy, Culture and Society (Oxford, Oxford University Press).

WEST,P. (1996)

Fathers, Sons and Lovers (Sydney, Finch Publishing).

YATES, L. (1986)

Theorizing inequality today, British Journal of Sociology of Education, 7 (2), pp. 119-134.

YATES, L. (1993a)

The Education of Girls: Policy, Research and the Question of Gender, (Melbourne, Australian Council for Educational Research).

YATES,L. (1993b)

Feminism and Australian state policy. Some questions for the 1990s, in: M.ARNOT \& K.WEILER (Eds) Feminism and Social Justice in Education (London, Falmer Press).

YATES, L. (1998a)

Constructing and deconstructing 'girls' as a category of concern, in A.MACKINNON, I. ELGQVIST-SALTZMAN \& A.PRENTICE (Eds), Education into the $21^{\text {st }}$ Century: dangerous terrain for women? (London, Falmer Press).

YATES,L. (1998b)

Education, in B.CAINE, M.GATENS, E.GRAHAME, J.LABALESTIER, S.WATSON \& E.WEBBY (Eds), Australian Feminism: a companion (Oxford, Oxford University Press).

YATES,L. \& MCLEOD,J. (1996)

"And how would you describe yourself?" Researchers and researched in the first stages of a longitudinal qualitative research project, Australian Journal of Education, 40 (1), pp.88-103.

YATES,L. \& LEDER,G.(1996)

Student Pathways: a review and overview of national data-bases on gender equity (Canberra, ACT Department of Education and Training). 


\section{University Library}

\section{- M M N E R VA A gateway to Melbourne's research publications}

Minerva Access is the Institutional Repository of The University of Melbourne

Author/s:

Yates, L.

Title:

The 'facts of the case': gender equity for boys as a public policy issue

Date:

1999

Citation:

Yates, L. (1999). The 'facts of the case': gender equity for boys as a public policy issue. In Masculinities at School, SAGE.

Publication Status:

Published

Persistent Link:

http://hdl.handle.net/11343/34792 